\title{
Editorial
}

\section{Major disasters will not go away!}

As we enter the 1990's, each one of us can look back over the past 20-25 years and recognize the rapidly evolving changes in population demographics and technology (medical or otherwise) that have occurred. These changes have not lessened the prospects for major mass casualty situations, but in fact have increased them dramatically: high speed massive transit systems; proliferation of nuclear power plants; volatile political situations in both Eastern and Western bloc nations; and the ever-present unpredictable weather conditions in Canada. This leads to the inescapable conclusion that disasters and the necessary involvement and integration of medical personnel in disaster planning and management will not go away!

Traditionally, practising physicians in Canada have shown little concerted and sustained interest in disaster medicine. The major involvement of medical doctors, with the exception of a few unusually keen areas in Canada (Canadian Physicians for Aid and Relief, Alberta Volunteer Disaster Response Association to name only a few), has been at the local hospital level. For the most par, disaster planning, or more specifically, hospital disaster planning committees have been regarded with lowly esteem by the attending medical staff of our hospitals. Usually, recent medical staff appointments were assigned to the disaster committee to help break them into the routine of hospital committee work. These committees, unlike some of the more active hospital committees (Quality Assurance, Medical Records, Pharmacy and Therapeutics) have never been considered frontline committees, in that their work was usually seen as boring and time-consuming. In most instances (as in Iny own personal case), this was the introduction to disaster preparedness at any level. Very few people have realized the true nature and value of active, well organized hospital, regional, provincial, and national disaster committees with their related activities.

Chairman, Disaster Planning Committee, Trauma Association of Canada.

Address correspondence to: Department of Surgery, Eaton Building North 9-234, Toronto General Hospital, 200 Elizabcth Street, Toronto, Ontario M5O $2 \mathrm{C4}$.
The time has come to shed this dreary image of disaster preparedness. The knowledge that major catastrophies can occur in any community in Canada has rekindled interest and awareness in this vital hospital/community activity. Major catastrophic events and mass casualty situations (real or threatened) occur frequently and without warning: Woodstock tomado, Mississauga train derailment, Hinton train derailment, Barrie tomado, Gander air crash, Edmonton tornado, Montreal flood. Unfortunately, with each event "new" knowledge is regained regarding medical personnel function in major catastrophe situations. These lessons are learned the difficult way, and often because of poor medical/ community preparation before the event. The medical profession has lagged behind other community agencies (police, fire, social service, etc.) in both awareness and preparation for mass casualty scenarios.

Major medical interest in mass casualty involvement waxes and wanes with the perceived threat of military action. Since 1945, fewer individuals have sought medical careers in the armed services. Additionally, civilian involvement in the armed services has declined since that time. Fortunately, there has been a cadre of enthusiastic supporters and recruits who are willing to use their time and effort and expertise gained in the military to become involved either in defence medical training or emergency/ mass disaster medical organizations. A handful of these people continue to exist in Canada. The long-term prospects for continued expertise in this area remains guarded. This was recognized in the recent Royal College of Physicians and Surgeons survey of Emergency Medicine (personal communication). Although disaster medicine has been identified as an important area of Emergency Medicine (and for that matter, for all members in the medical profession), a structured, formalized, concentrated exposure in this area was absent in most medical programs across the country.

Medical education for mass casualty preparedness has occurred sporadically. The major program for continued education has been through the Department of Health and Welfare Canada, and its "Arnprior course." Many participants in this course have felt that this was not an optimum exposure for physician awareness and preparedness for 
mass casualty situations. To remedy some of these difficulties, the Trauma Association of Canada organized a recent continuing medical education conference (MEDS - Medical Energency Disaster Strategies) in an effort to upgrade the awareness and knowledge base for disaster management amongst physicians, nurses and hospital administrators. An assembled group of 170 disaster planners (130 physicians) were educated for a two-day period in an effort to spread the knowledge and enthusiasm for disaster planning that is necessary in the 90's. The Trauma Association of Canada and the Canadian Association of Emergency Physicians have jointly pledged to continue to work together in this area to cducate not only emergency physicians and surgeons, but all members of the medical community with respect to their individual, vital roles in disaster medicine regardless of specialty of practice.

I believe that we can go farther than the MEDS conference of January 1988. In this regard, I would make the following recommendations:

1 Establishment of a formal mechanism to ensure education of our physicians and surgeons in the area of disaster management. This may be through separate programs such as are planned with the emergency medicine or the surgical resident in specially designed courses.

2 Better coordination and liaison with Health and Welfare of Canada to ensure more medical involvement at the national level and input into major disaster planning programs at that level.

3 Establishment of standard triage codes and research tocls to provide us with accurate data bases, so that we can continue to educate ourselves in the problems of disaster management.

4 Encourage medical involvement at the local level so as to better educate our non-medical colleagues (police, fire, ambulance, social services, etc.) in medical responses and the responsibilities during the time of a major catastrophe.

5 Education at the public level of medical responses in a mass casualty scenario, i.e.: identify under what circumstances medical practices are changed, and where practices are unchanged.

I believe that the medical profession has a long way to go to improve its involvement in mass casualty situations. Whether we like it or not, the problem of triage and mass casualty scenarios will not go dway. I think that it is incumbent upon each one of us to encourage our own involvement and education in this area on behalf of our patients.

\section{Les grands sinistres ne disparaitront jamais!}

A l'approche des années 90, chacun c'entre nous peut regarder les 20-25 dernières années pour reconnaitre l'évolution rapide des changements démographiques et technologiques (médicaux ou autres) ayant survenu dans cette période. Ces changements n'ont pas diminué les possibilités de catastrophes majeures, mais les ont rendues plutôt plus dramatiques: par un système de transport de masse ultra-rapide; par la prolifération des centrales nucléaires; par des situations politiques volatiles tant dans le bloc des nations de l'Est que de l'Ouest; et par l'omniprésence au Canada de conditions climatiques imprévisibles. Ceci amène les conclusions évidentes que les sinistres ainsi que l'implication obligatoire du personnel médical dans la planification et la conduite lors de ces désastres seront toujours omniprésents.

Traditionnellement, les médecins pratiquant au Canada ont montré un intérêt peu soutenu et concerté dans le domaine de la médecine lors des sinistres. Leur implication majeure, à l'exception de quelques rares associations inhabituellement enthousiastes au Canada (Canadian Physicians for Aid and Relief, Alberta Volunteer Disaster Response Association pour ne nommer que quelques-unes) était au niveau hospitalier local. En général, la planification lors des sinistres, ou plus spécifiquement les comités hospitaliers de planification, ont été moins appréciés par l'équipe médicale dans nos hôpitaux. Habituellement, les jeunes recrues de l'équipe médicale étaient désignées au comité de sinistres pour les habituer à la routine hospitalière des travaux de comité. Ces comités, contrairement à ceux plus actifs (comme ceux de l'acte médical, du dossier médical, de la pharmacie et thérapeutique) n'ont jamais été considérés comme des comités d'avant-garde car leur travail était habituellement lent et ennuyeux. Dans la plupart des cas (expérience personnelle), ceci était l'introduction à un état d'alerte préventive aux sinistres à tous les niveaux. Très peu de gens réalisent la nature et la valeur des activités des comités actifs et bien organisés, soit hospitaliers, régionaux, provinciaux ou nationaux.

Le temps est venu d'éclaircir ce sornbre tableau de l'état d'alerte prêventive en cas de sinistre. En sachant que des sinistres majeurs peuvent survenir dans n'importe quelle communauté au Canada, l'intérêt et la conscience furent ravivés dans cette activité hospitalì̀re communautaire vitale. Les sinistres majeurs et les catastrophes communautaires (réelles ou menaçantes) surviennent 
fréquemment sans préavis: la tornade de Woodstock, les déraillements de train de Mississauga, celui de Hinton, la tornade de Barrie, l'écrasement de l'avion à Gander, la tomade d'Edmonton, l'inondation de Montréal. Malheureusement, avec chaque événement, des connaissances "nouvelles" sont acquises concernant le fonctionnement du personnel médical lors de ces situations catastrophiques. Ces leçons sont apprises laborieusement souvent à cause d'un manque de préparation de la communauté médicale avant l'événement. La profession médicale a traîné le pas derrière les autres agences communautaires (police, pompiers, services sociaux, etc.) tant dans la reconnaissance que dans la préparation pour des scénarios de desastres.

L'intérêt médical dans l'implication lors des désastres varie avec la perception d'une action militaire menaçante. Depuis 1945, le recrutement dans une carrière médicale dans les forces armées a diminué. Il en est de même pour l'implication des civils dans les forces armées. Heureusement, il y avait un cadre de partisans enthousiastes et de recrues qui sont prêts à offrir leur temps et effort en même temps qu'une expertise gagnée dans les forces armées afin de s'impliquer, soit dans l'entraînement médical de défense ou dans les organisations médicales lors de désastres collectifs. Une poigné de ces gens continuent a cuvrer au Canada, A long terme, les perspectives d'avenir pour une expertise continue dans ce domaine demeurent réservées. Ceci a été reconnu par l'étude sur la médecine d'urgence du Collège Royal des médecins et chirurgiens (communication personnelle). Même si la médecine de sinistre a été identifiée comme une partie importante de la médecine d'urgence (et quant à ça, pour tous les membres de la profession médicale), une exposition structurée, formelle et concentrée dans ce domaine était absente dans la majorité des programmes médicaux a travers le pays.

L'éducation médicale pour une préparation aux sinistres tait présente occasionnellement. Le programme majeur pour une éducation continue était par l'entremise du Département de Santé et Bien-Etre du Canada et son "Amprior Course." Plusieurs participants dans ce programme ont ressenti que ceci n'était pas l'exposition optimale pour une prise de conscience des médecins aux situations de désastres communautaires. Afin de remédier a quelques-unes de ces difficultés, l'Association de Trauma du Canada a organisé récemment une conference médicale (MEDS - Medical Emergency Disaster Strategies) dans un effort visant à augmenter la prise de conscience et la connaissance de base pour une meilleure conduite lors de sinistres parmi les médecins, infirmières et administrateurs hospitaliers. Un groupe de 170 planificateurs (130 médecins) était éduqué pour une période de deux jours dans un effort de semer la connaissance et l'enthousiasme pour une planification qui sera nécessaire dans les années 90. L'Association de Trauma du Canada et l'Association Canadienne pour la médecine d'urgence ont d'un commun accord juré de continuer le travail ensemble dans ce domaine afin d'éduquer non seulement les médecins et chirurgiens dans leur spécialité mais tous les membres de la communauté médicale en raison de leur rôle individuel vital dans la médecine de sinistre sans tenir compte de leur spécialité.

Je crois qu'on pourrait aller plus loin que la conférence MEDS de janvier 1988. A cet égard je recommanderais: 1 L'établissement d'un mécanisme formel afin d'assurer l'éducalion de nos médecins et chirurgiens dans le domaine de la conduite à tenir lors des sinistres. Ceci peut se faire à travers des programmes séparés comme ceux đéjà planifiés en médecine d'urgence ou lors de la résidence chirurgicale avec des cours spécialement conçus.

2 Une meilleure coordination et liaison avec Santé et Bien-Etre du Canada afin d'assurer une plus grande implication médicale au niveau national et une participation dans la planification des programmes lors des sinistres à ce niveau.

3 L'établissement de normes de triage et d'outils de recherche afin de nous fournir des données de base exactes afin qu'on puisse continuer à nous eduquer dans le domaine de la concuite à tenir lors des sinistres.

4 Encourager l'implication médicale au niveau local afin de mieux éduquer nos callègues professionnels nonmédicaux (police, pompiers, ambulanciers, services sociaux etc.) concernant notre rôle et nos responsabilités lors de ces sinistres.

5 L'éducation du public par un scénario de sinistres communautaires quant à la réponse de l'équipe médicale, par exemple: identifier dans quelles circonstances les pratiques médicales sont changées et dans quelles autres circonstances elles ne le seront pas.

Je crois que la profession médicale a beaucoup à faire afin d'atméliorer son implication dans les situations de sinistres. Qu' on le veuille ou non le problème de triage et celui des scénarios de sinistres seraient toujours omniprésents. Je pense qu'il incombe à chacun d'entre nous d'encourager notre propre implication et education sur ce sujet pour le bénéfice de nos patients. 